\title{
Implementation of Microservices Architecture in Learning Management System E-Course Using Web Service Method
}

\author{
Fachru Dahri' ${ }^{1)}$, Andi Marwan Elhanafi' ${ }^{2}$, Divi Handoko ${ }^{3)}$, Nur Wulan ${ }^{4)}$ \\ 1)2/3)4 Universitas Harapan Medan, Indonesia \\ ${ }^{1)}$ fachru.dahri@gmail.com, ${ }^{2)}$ andimarwanelhanafi@gmail.com, ${ }^{3)}$ divihandoko@gmail.com, \\ ${ }^{4)}$ nurwulanstth@gmail.com
}

Submitted : Dec 16, 2021 | Accepted : 4 Jan, 2022 | Published : Jan 4, 2022

\begin{abstract}
Learning Management System is already too much but there are many problems that make people think about using it because it is difficult to maintain the system, so to build a system this takes a lot of time because the basis for developing the system is monolith-based and difficult to develop if the system development team grows or change. Learning Management System needs to be implemented for easy access to learning, because online learning is very important to be a good alternative. From these problems led to the idea to create a Learning Management System in which it can solve services and communicate between services to facilitate efficient development. This study aims to apply the Web Service Implementation Methodology used in building a Learning Management System for an E-Course that facilitates online learning by implementing web services. To perform inter-service solving the methodology used in making this application is the web service method which is implemented on the microservices architecture. Programming languages for differentiating services are PHP and JavaScript. For the user interface, ReactJS is used as the API data manager for each service and the database uses MySQL. This application will later be used as a medium to facilitate online learning, there are members (users) as student actors and admins to manage mentor and course data that will be displayed.
\end{abstract}

Keywords: API; Architecture Microservices; Learning Management System; Monolith; Web Service

\section{INTRODUCTION}

There has been a lot of learning to implement a Learning Management System but there are many problems that make people think of using it because it is difficult to maintain the system, so to build a system this takes a lot of time because the basis for developing the system is monolith-based and difficult to develop if the system development team adds or changes. Learning Management System needs to be implemented for easy access to learning, because online learning is very important to be a good alternative. Learning Management System is an application that has an automatic administration role for various learning activities (Mustafa et al., 2018)

To be able to develop a Learning Management System that is good in development and has the potential to be large, so many developers are designing the web application by implementing a microservices architecture. Implementation Microservices architecture is simply an architecture by breaking the application into parts of small specific functions (JAYANTO, 2017), By splitting the service, it will make it easier for developers to develop web applications. implementing microservices architecture makes application code less independent and therefore allows independent testing of applications and makes scalability easier (Mufrizal \& Indarti, 2019). Basically, other architectures such as Monolithic architecture have been widely applied to general websites. But here the author wants to know how far the level of efficiency of the Microservices architecture if it is applied in website development. Web Service does not escape the explanation of JSON (JavaScript Object Nation). JSON is a lightweight data exchange format, easy for humans to understand and write, and easy to translate and generate (generate) by computers. Writing data format using JSON in short because by using javascript notations such as square brackets [] and curly braces \{\}(Choiri et al., 2017).

*name of corresponding author 
From these problems the author wants to do a design that can build a Learning Management System for an ECourse that facilitates online learning with the implementation of Web Services which will be designed with a microservices architecture. The application development method used is the Web Service Implementation Method (Rafiqi et al., 2019). Indeed, there are already websites that use the Microservices architecture but it is applied in companies or institutions that are technology literate. This is one of the reasons why it is difficult to develop complex systems when there are many teams or intervening between developers. Therefore, it is hoped that the implementation of the Microservices architecture on the Learning Management System E-Course with the Web Service method can overcome difficulties in developing complex web applications and systems.

\section{Learning Management System}

\section{LITERATURE REVIEW}

Learning Management System is an application that provides facilities for making learning media systems directly as software for the delivery of learning programs, administration, reporting and documentation. The features that can be used in the LMS are managing user access rights, managing learning courses, managing learning materials, managing activities, managing grades, displaying grade transcripts, and managing e-learning displays (Dhika et al., 2020).

E-Learning is a type of teaching and learning process that allows the delivery of teaching materials to students using the internet, intranet or other computer network media. e-learning as an alternative to learning in various educational institutions is increasing in line with developments in the field of communication and information technology. There are various types of E-Learning implemented in schools, one of which is the Learning Management System (LMS) (Aditra, 2016).

In the E-Course an educational concept which puts all 5 material Learning on a website is not only lessons but exams, all discussion questions related to learning are stored and accessed through an integrated website. So that lecturers can monitor students when online. The use of E-Course learning media to increase motivation and students to be more active in class to improve direct current machine learning outcomes (Senja, 2016).

\section{Microservices}

Microservice architectures are used as alternative to monolithic applications because they are simpler to scale and more flexible. Microservices require a careful design because each service component should be simple and easy to develop (Messina et al., 2016).

Microservice architecture is an alternative architecture that is more scalable and more flexible. In the microservice architecture, information systems are designed to be distributed and provide services in a more focused and specific way. Big problems will be broken down into several small solutions compiled in one service, where each service has its responsibility (Munawar \& Hodijah, 2018).

From the point of view of the microservices paradigm, a key concept in resilient engineering is insulation. If one component of the system fails, the failure will not cascade / affect the performance of the other components. Thus, the problem can be isolated and the rest of the other system components can continue to work. In a monolithic system, if a service fails, then everything stops working. The system can be run on multiple redundant machines to reduce the chance of system failure. On the other hand, with microservices, a system can be built that can handle a total service failure because the service functionality of the system has been confined within a clear boundary (Suryotrisongko, 2017).

In terms of technology, microservices technology architecture is one of the technologies that is often used in recent times due to its scalability. A particular characteristic of microservices architecture is that it assembles applications into small independent services, communicates well with each other, and uses lightweight mechanisms to serve business purposes. Service communication with each other depends on the needs of the application used. In addition, thanks to its scalability, the costs of developing microservices will be relatively cheaper (Iqbal et al., 2021).

\section{Web Service}

Web service is a collection of computational data that can be developed with platforms and interfaces of different programming languages to solve problems of data exchange and data management, which can be accessed via the internet or intranet networks with certain protocol standards. (Aliyah et al., 2017).

Web services provide communication standards between different software applications. Web services use communication technologies such as SOAP (Simple Object Application Protocol), WSDL (Web Service Description Language), and XML (Extensible Markup Language) sent via HTTP (Hypertext Transport Protocol). With the use of this technology, web services offer convenience to bridge the exchange of information used. Web services are derivatives of web applications, and modular applications can be created that can be published, deployed, and generated between webs (Suhaibi, 2018).

*name of corresponding author 
A web service is a software system designed to support interoperability and interaction between systems on a network. Web service is used as a facility provided by a website to provide services (in the form of information) to other systems so that other systems can interact with the system through these services (Rofiq \& Susanto, 2017).

\section{METHOD}

Using the web service method, developers can do it easily when implementing microservices architecture in the case of the Learning Management System E-Course. the development method will describe how the communication between services and web services on microservices works. By designing the flow and evaluating the structure of the microservice architecture, it is possible to determine how many web services will be created and broken down for each service and connect one service to another to become one application.

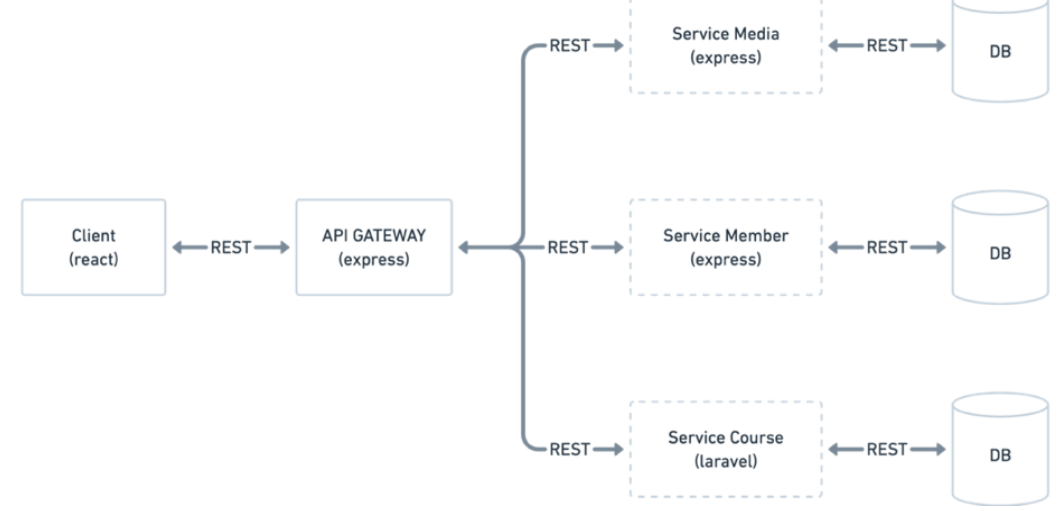

Fig. 1 E-Course System Web Service for Microservices

Fig. 1 it can be seen that the client uses the REST API to communicate with the API Gateway where the API Gateway is a gateway for communication between services that serves as the main gateway for microservices, apart from being a gateway, the API Gateway also has an authentication role and also functions for API management. Here API Gateway uses JSON Web Token (JWT) authentication. The working scheme after successfully passing through the API Gateway is a request process that will be forwarded to the API destination, such as service media, service users, and service courses. Each service communicates with each other using REST as the HTTP protocol.

\section{RESULT}

This research produces a website-based application that has the name E-Courseku, on this website, there is an interface provided for members having several menus such as login to enter, register as registration if you don't have an account, forget password if a member forgets account password, settings page for changing member data or uploading profile photos, what classes are available, and being able to enroll a course that will belong to the member so that they can watch the video course they already have.

The home page contains about the website and displays several courses that are owned so that users can see what is on the e-course website.
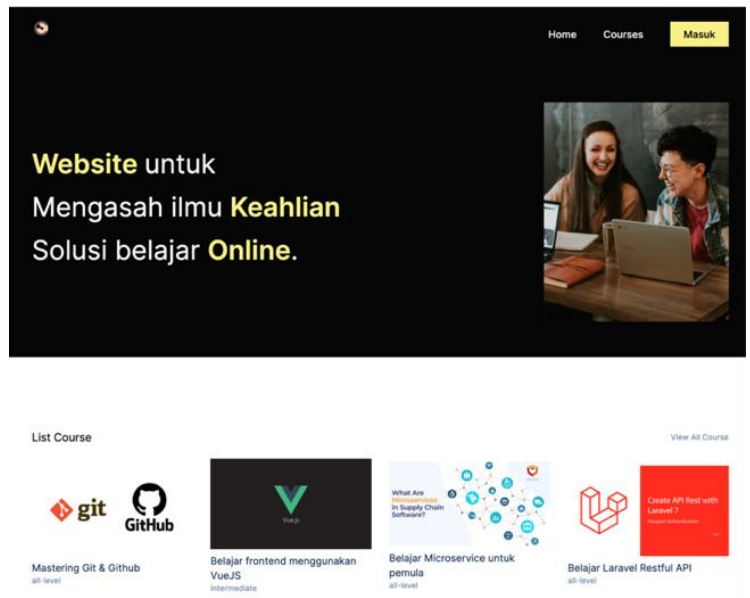

Fig. 2 Home Page

*name of corresponding author 
There is a course page to view all available courses and make it easy to find the courses that user members want.
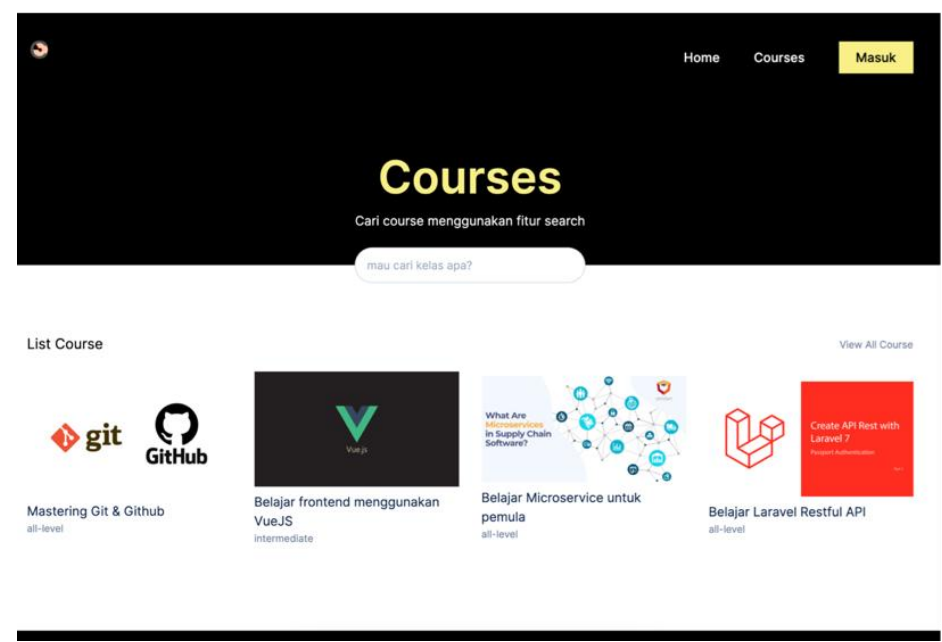

Fig. 3 General Course Page

Before entering my class page, you must first log in as an authentication user.

c

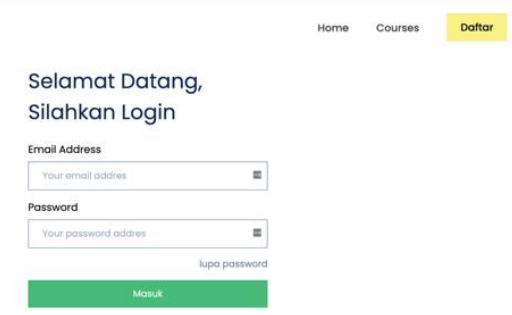

Fig. 4 Login Page

When a user member does not have an account to log in, a registration page is available to register a member user account to access my class page.

c

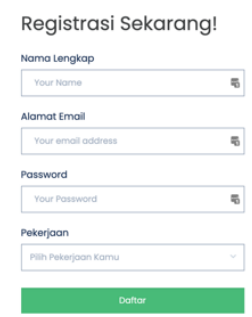

Fig. 5 registration Page

The user can reset the password when the user accidentally forgets the account password and the reset password will be sent to the email.

C

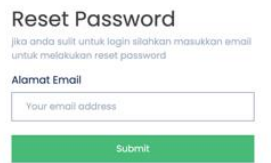

Fig. 6 Reset Password Page

*name of corresponding author 
After authenticating the login, use the user to be directed to my class page.

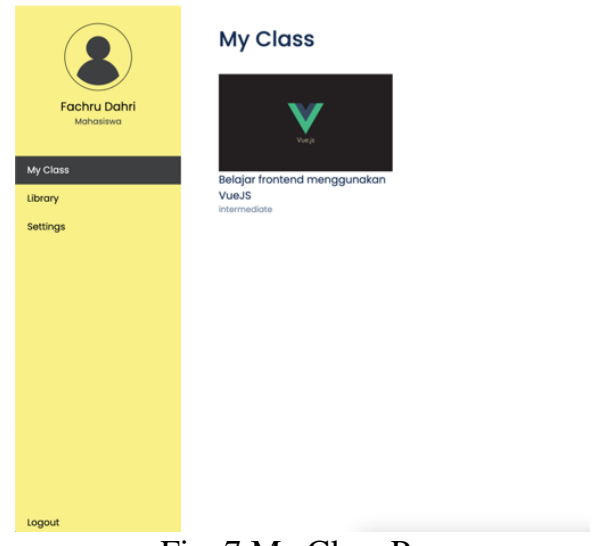

Fig. 7 My Class Page

When selecting a course, the general course page will display the details of the selected course.

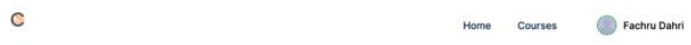

Belajar frontend menggunakan VueJS

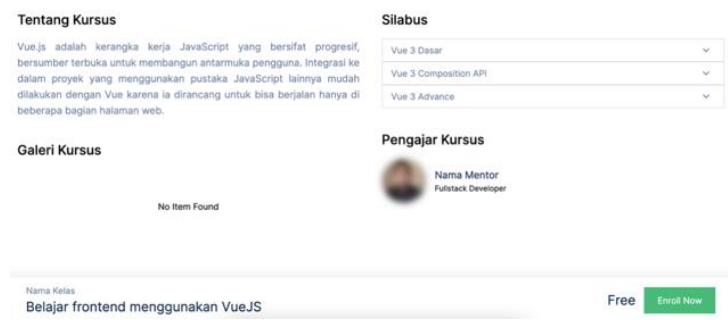

Fig. 8 Detail Course Page

When the user has enrolled a class on the course detail page, it will be directed to the learning process page.

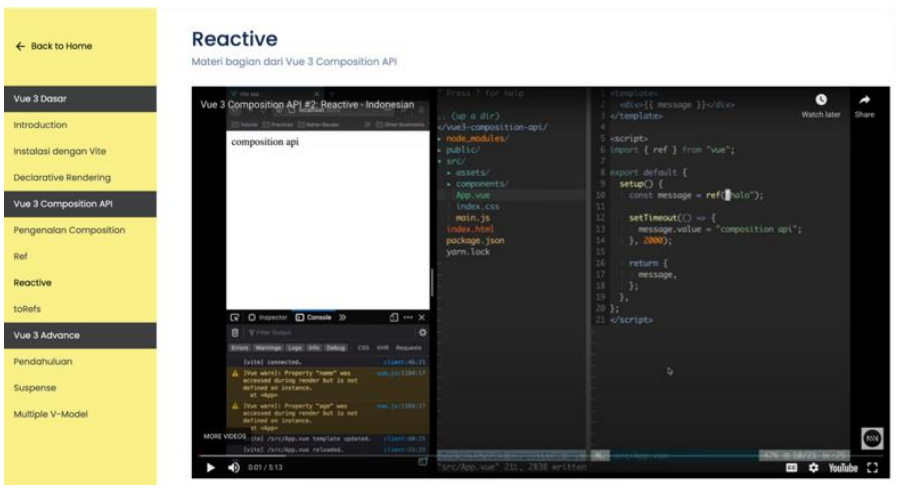

Fig. 9 Learing Process Page

\section{DISCUSSIONS}

In this architectural modeling, it is explained that the microservice architecture used in this e-course implements a web service where each service uses a REST API for communication between services. Each service has one or more separate subdomains. At this stage, the author uses 3 services, namely media services as media data storage such as images, user services containing user data who register on the e-course system, and service courses as data storage for each course that is followed. Each service is separated between logic and HTTP requests. 
In the media service flow, the client requests the API gateway by sending a body that has a key image with base64 format, then API gateway 23 sends the same request to the media service, and the media service sends back a response that has several keys such as status, data, in the data has a key id and URL where the URL is the image link.

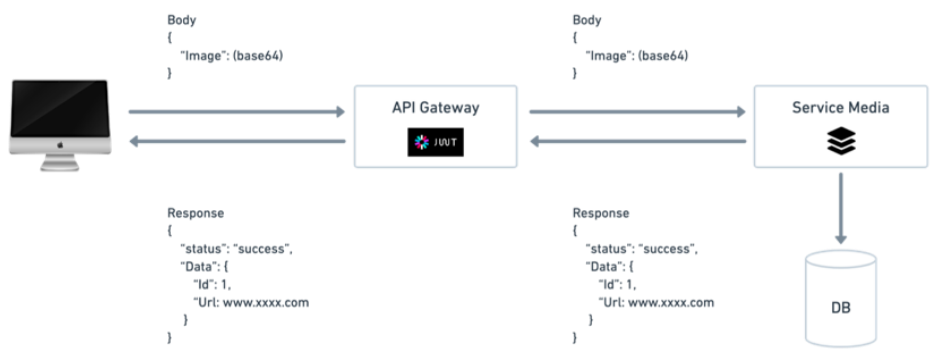

Fig. 10 Flow Service Media

In the flow service, the user client makes a request according to the field entered by the user to the API gateway then the API gateway forwards to the service user and the service user sends a response to the API gateway with several keys such as status, data, and in the data, there are an email key, name, and roles. Then the API gateway forwards the response to the client with a different key, namely the status key, data, in the data there is a key token and refresh_token.

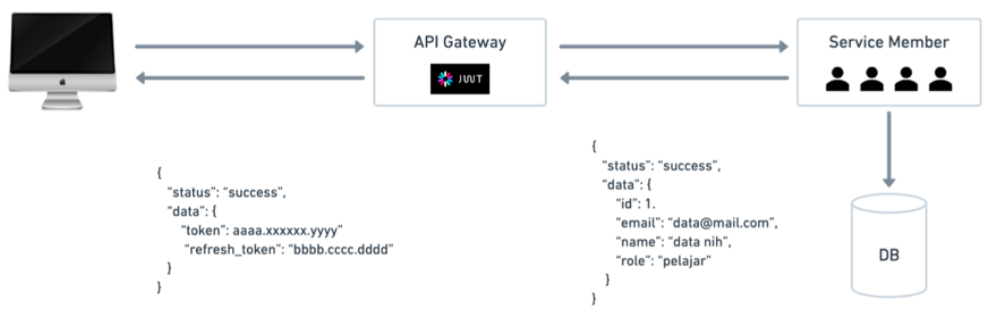

Fig. 11 Flow Service User (Member)

For the service course flow, the client requests the API gateway and the API gateway continues the request as a verified request to the service course to get a response, and the response is sent to the API gateway and then forwarded to the client.

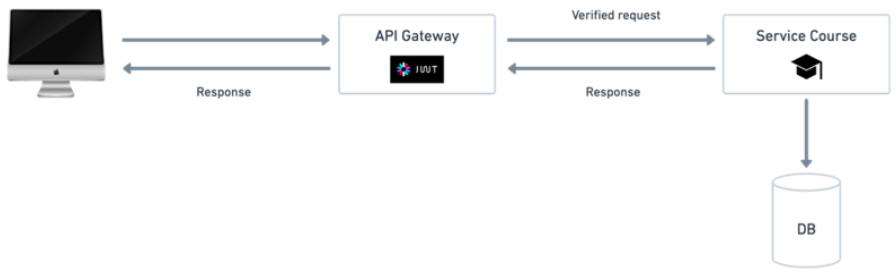

Fig. 12 Flow Service Course

\section{CONCLUSION}

The results of the research aim to make it easier for developers to develop Learning Management System applications that have many features and make collaboration between developers more efficient because they do not depend on one programming language in making applications because it is enough to break services and unify them. With the implementation of the Learning Management System here, it uses three services that communicate with each other using the HTTP protocol by applying the RESTFUL API to each service to communicate and using the API gateway as a connecting gateway between the service and the client side, making the application one or interconnected. In this study, the REST API uses Remote Procedure Invocation communication, it is hoped that in future developments it can be implemented using Messaging (Message Broker) communication and development can implement microservices architecture with the web service gRPC method.

\section{ACKNOWLEDGMENT}

in the accomplishment of this research, this time $i$ am utilizing to thank all the people who have concerned with this research. Primarily i would thank Allah for being able to complete this research with success. then i would

*name of corresponding author 
like to thank my parents and dear friend whose valuable support has been very helpful in various phases of the completion of this research.

\section{REFERENCES}

Aditra, G. (2016). Pelatihan Penggunaan E-Learning Berbasis Media Sosial. SEMINAR NASIONAL PENGABDIAN KEPADA MASYARAKAT. https://eproceeding.undiksha.ac.id/index.php/senadimas/article/download/254/156

Aliyah, I., Asrowardi, I., \& Sahlinal, D. (2017). Implementasi Web Service Dalam Monitoring Pendapatan Perusahaan Dari Penjualan Tiket Bus Di Perum Damri Kantor Cabang Bandar Lampung. 1-6.

Choiri, T., Dengen, N., \& Islmiyah. (2017). Web Service untuk Web Profil SMP Negeri 2 Rantepao Toraja Utara. 2(1).

Dhika, H., Destiawati, F., Surajiyo, S., \& Jaya, M. (2020). Implementasi Learning Management System Dalam Media Pembelajaran Menggunakan Moodle. Prosiding Seminar Nasional Riset Information Science (SENARIS), 2(0), 228-234. http://tunasbangsa.ac.id/seminar/index.php/senaris/article/view/166

Iqbal, M., Informatika, J., Indonesia, U. I., Dirgahayu, T., Informatika, J., Indonesia, U. I., Putro, H. P., Informatika, J., \& Indonesia, U. I. (2021). Implementasi Arsitektur enterprise Pola Vending Machine pada Teknologi Microservices. AUTOMATA, 2.

JAYANTO, D. P. (2017). Informasi Web Application Backend Development of "Siap ": " Sistem Informasi Aspirasi Dan Pengaduan Masyarakat "Application Based on Web Using Microservice Springboot. 156.

Messina, A., Rizzo, R., Storniolo, P., \& Urso, A. (2016). A Simplified Database Pattern for the Microservice Architecture. The Eighth International Conference on Advances in Databases, Knowledge, and Data Applications, June, 35-40. https://doi.org/10.13140/RG.2.1.3529.3681

Mufrizal, R., \& Indarti, D. (2019). Refactoring Arsitektur Microservice Pada Aplikasi Absensi PT. Graha Usaha Teknik. Jurnal Nasional Teknologi Dan Sistem Informasi, 5(1), 57-68. https://doi.org/10.25077/teknosi.v5i1.2019.57-68

Munawar, G., \& Hodijah, A. (2018). Analisis Model Arsitektur Microservice Pada Sistem Informasi DPLK. Sinkron: Jurnal Dan Penelitian Teknik Informatika, 3(1), 232-239.

Mustafa, P. Y. D. M., Jusak, \& Erstiawan, M. S. (2018). Rancang Bangun Aplikasi Learning Management System Berbasis Web Dengan Menggunakan Model SCORM Pada SMA Kartika. Jsika, 7(1), 1-12.

Rafiqi, M. D., Subyantoro, E., \& W, D. K. (2019). Implementasi Arsitektur Microservice Pada Aplikasi Online Travel Tourinc. Karya Ilmiah Mahasiswa Manajemen Informatika, 1(1), 1-10.

Rofiq, F. N., \& Susanto, A. (2017). Implementasi RESTful Web Service untuk Sistem Penghitungan Suara Secara Cepat pada Pilkada Implementation of Restful Web Servicefor Quick Count System of MayorElection. Eksplora Informatika, 6(2), 159-168.

Senja, M. (2016). PENGEMBANGAN MEDIA PEMBELAJARAN E-COURSE UNTUK MENINGKATKAN HASIL BELAJAR MAHASISWA TEKNIK ELEKTRO PADA MATA KULIAH MESIN ARUS SEARAH DI UNIVERSITAS NEGERI SURABAYA. 2, 627-633.

Suhaibi. (2018). IMPLEMENTASI WEB SERVICE MENGGUNAKAN LIBRARY NUSOAP.

Suryotrisongko, H. (2017). Arsitektur Microservice untuk Resiliensi Sistem Informasi. Sisfo, 06(02), 231-246. https://doi.org/10.24089/j.sisfo.2017.01.006

*name of corresponding author 